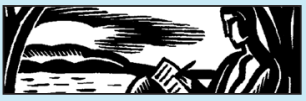

\title{
Mobilizing Grief and Remembrance with and for Networked Publics: Towards a Typology of Hyper-Mourning
}

\author{
Korina Giaxoglou
}

The Open University, UK

\begin{abstract}
The past decade has seen an intense mobilization of grief and remembrance on social media linked to the injunction to inscribe, share, and curate life and death in the here-and-now. This article navigates the heterogeneity of these practices, using the term hyper-mourning to point both to the conditioning of mourning by the affordances of hyper-connectivity and to debates around these emerging forms of mourning as being emotionally hyperbolic and 'inauthentic' reactions to death events. Based on the discussion of select examples, I sketch out a typology of hyper-mourning, depending on the different story positions of teller, co-teller, or witness from which such performances are produced. As I argue, these different performances become typically associated with particular modes of affective positioning made available to the recipients of these shared stories-namely positions of proximity or distance to the death event and the dead, the networked recipient(s), and the emotional self. This typology proposes a small stories approach to hyper-mourning practices, which are organized around the mobilization of grief and remembrance for connecting networked audiences around identities, affect, and moral values dis/alignments. The article contributes to the interdisciplinary study of digital cultures of memory, affect, and identities.
\end{abstract}

Keywords: mourning, memorialisation, affect, narrative 


\section{INTRODUCTION}

On Friday 17 May 2019, news of the death of Grumpy Cat was shared via the Instagram account realgrumpycat, which has nearly $2.7 \mathrm{~m}$ followers (Figure 1). Grumpy Cat, known on social media for her gloomy gaze, was one of the first petfluencers, i.e. pets used by their owners for advertising and publicity purposes. The post announcing her death attracted more

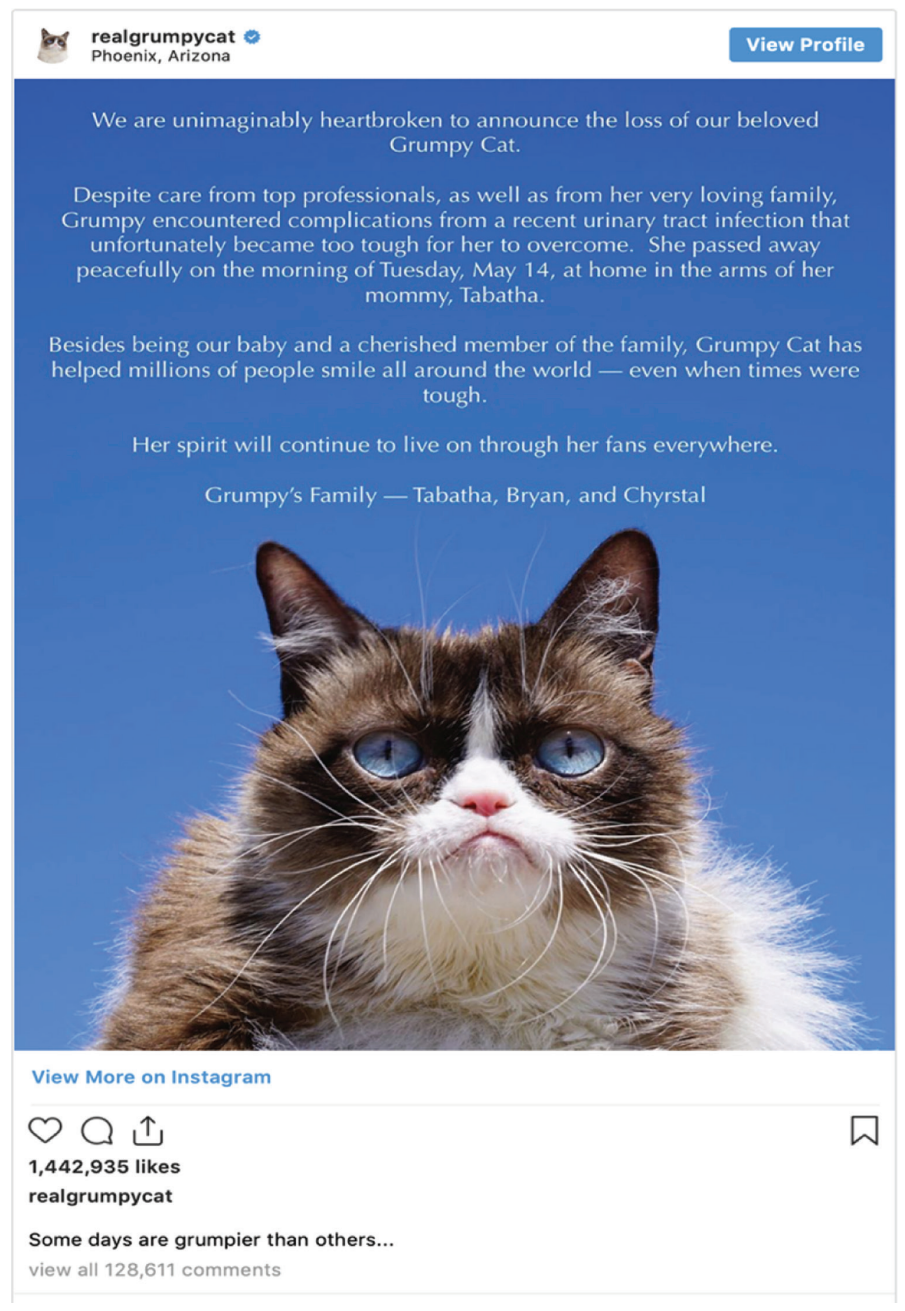

Figure 1. Instagram announcement of Grumpy Cat's death in May 2019. 
than one million likes and 128,611 comments and hit the news headlines. ${ }^{1}$ This mourning frenzy expressed through likes, shares, and comments-by now, typical features of interactivity and participation in almost all digital communication ${ }^{2}$ - attests to the mediatization of death announcements for popular entertainment, also known as deathtainment.

Deathtainment is connected to a growing demand for portrayals and images of death in the context of a contemporary cult of death. This celebration of death is not entirely new, however. As death historian Philippe Ariès notes, ${ }^{3}$ the nineteenth and twentieth centuries had seen the cult of tombs and cemeteries in the context of a romantic treatment of death and memory. The contemporary cult of death, as described by Dina Khapaeva, ${ }^{4}$ emerging in the late 1980 s and the 1990s, has seen a much broader and diverse range of related phenomena, including, for example, the rise of dark tourism to places of death and suffering; new enthusiasm for genres, such as gothic, horror, slasher, vampire and zombie films; the integration of corpse chic and skulls in mainstream fashion, as well as the amplification of death online.

In social media contexts, popular interest in death online is not limited to death news for entertainment and viral sensations like the Grumpy Cat. It also covers a felt imperative to instantly react to, document, and memorialize death that is emotionally significant to individuals and communities as well as mass-mediated death turned into worldwide events ${ }^{5}$ and spectacles in line with media logics. ${ }^{6}$ These logics foster the momentby-moment updating of what Steven Livingston and Lance Bennett refer to as event-driven news, 'activities that are, at least at their initial occurrence, spontaneous and not managed by officials within institutional settings. ${ }^{7}$ In environments of continuous or rolling news coverage online, for example, death often features as a newsworthy 'big' event, reported cumulatively through a series of frequent and short updates, inviting readers and viewers to share their reactions.

This mode of participatory spectacularization of death, ${ }^{8}$ where grief is mobilized for connecting publics around intense feelings about a specific death in the here-and-now, has a precedent in the public enactments and media coverage of mourning for iconic figures. The monumental scale of public mourning for the sudden death of Diana, Princess of Wales in a car crash on 31 August 1997, still stands as an exemplary case of the narrativization of death and mourning as a public and media spectacle organized around contrasting identifications and meanings related to a range of cultural themes and political issues. ${ }^{9}$ As Richard Johnson notes,${ }^{10}$ mourning for Diana's death also activated debates around the rhetorics of public grieving, referencing its two sides: chaos, enacted in the popular outpouring of grief, versus policing, the measured and emotionally distant 
reaction, including the negation of the authenticity of popular emotional expressions branded as hyperbolic. Similar debates surface around the sharing of mourning or condolences on social media, following the death of a public figure ${ }^{11}$ or a family member. ${ }^{12}$

Among scholars there is still an apparent lack of consensus about how best to approach the multiple enactments of mourning performances. The study of the online mediatization of such practices raises additional questions relating to the complex production and representation of self and culture online. For auto/biography scholars Anna Poletti and Julie Rak, ${ }^{13}$ concerned with the study of identity technologies, 'the persistence of narrative as a frame for understanding how online identity is formed' 14 needs to be revisited given how media convergence and digital affordances have changed the construction and communication of identities.

In this article, I argue that a narrative lens to the construction of self and culture in the performances of mourning in social media can still prove useful, provided that the understanding of narrative is updated with insights from the small stories research paradigm. ${ }^{15}$ This paradigm has proved apt for encompassing the non-canonical forms of interactional storying in digital contexts. Applying small story insights into the study of performances of public grieving and memorialization online, I propose a typology that foregrounds the heterogeneity of such practices based on their key narrative ingredients. I use the term hyper-mourning to highlight their conditioning by the hyper-connection affordances, i.e. their digital features, and their evaluation as hyperbolic, defined through emotional reactions that often accompany them and which are seen as excessive.

I start with a brief discussion of offline popular forms of vernacular memorialization. I then move on to consider a selection of the key dimensions of the extension of mourning and memorialization online, highlighting some of the continuities involved and key dimensions of variation. Based on select examples, discussed only summatively here ${ }^{16} \mathrm{I}$ point to the typical narrative positions that such practices afford to those involved, and I propose a typology of sharing grief and remembrance in the here-and-now as a mode of hyper-mourning associated with particular types of affective positioning to the death event and the dead, the (networked) audience, and the emotional self.

\section{TRIBUTES TO THE DEAD}

Paying tribute to the dead has long been part of human culture as a form of popular entertainment and as a way of uniting against the threat that death poses to the social order and to oneself through acts of collective meaning-making. This coming together of people in the face of death 
is aptly described in a scene of public mourning in Don De Lillo's novel White Noise:

They were there to attend tributes to the dead. Processions, songs, speeches, dialogues with the dead, recitations of the names of the dead. They were there to see pyres and flaming wheels, thousands of flags dipped in salute, thousands of uniformed mourners. There were ranks and squadrons, elaborate backdrops, blood banners and black dress uniforms. Crowds came to form a shield against their own dying. To become a crowd is to keep out death. To break off from the crowd is to risk death as an individual, to face dying alone. Crowds came for this reason above all others. They were there to be a crowd. ${ }^{17}$

In addition to the desire of forming a crowd, public mourning is also mobilized around the desire to somehow mark the site of death and commit to continuing remembrance of the beloved. Such memorial commitment is particularly felt in the case of the loss of a loved one; it drives the creation of vernacular or bottom-up memorialization, in for instance roadside memorials (RDMs), which mark the place of an unexpected death.

As John Belshaw and Diane Purvey's study on RDMs in British Columbia has shown, these idiosyncratic personal memorials 'restore death to a place in day-to-day life'18 and turn death-often the death of young males who lose their life in road accidents-into an everyday memorial, which may also be a 'warning' to others. The shrines to young males that Belshaw and Purvey examined were often filled with offerings, such as toys, greeting cards and animals; these represented the departed youngsters as innocent children and constructed an idealized identity for the dead. In other cases, they included bottles of alcohol and cigarettes as items celebrating youthful hedonism. Irrespective of their particular format, roadside shrines mark death on the site where it happened, providing passers-by with a material and emotionally raw expression of grief. ${ }^{19}$

In these personal memorials, individual grief attains a collective force as public mourning. In addition, the situatedness of these memorials in space helps increase the visibility of the dead in line with media logics that foreground incidents of young individuals' tragic and sudden death as newsworthy stories of human interest. Shrines, which are often instantly constructed after a crash, become ideal sources for television footage or newspaper front pages. ${ }^{20}$

More recently, public tributes posted on the social media profiles of the dead or in online memorials are drawn upon as authentic material for rolling death news-stories. In addition to providing journalists with news sources, social media offer new contexts for engaging with personal 
memorialization in more or less public modes, forming networked, affective 'crowds' in the face of loss where people can mourn 'alone, together'. ${ }^{21}$ The next section discusses the turn to 'sharing', which has fostered this surge of collective and personalized memorialization in digital environments.

\section{SHARING LIFE AND DEATH ONLINE}

The injunction to share ordinary moments of everyday life in digital contexts, such as Facebook, dates to the early 2000s. In the age of social media, sharing has become a pervasive metaphor for experience. Social media platforms have been urging users to share their photos (e.g. Flickr), news (e.g. Twitter), moments (e.g. Facebook) and stories (e.g. Snapchat, Instagram, and Facebook). As Nicholas John notes in his book The Age of Sharing, ${ }^{22}$ this pervasive use of the verb share as a feature on social media platforms' landing pages and promotional descriptions, but also as clickable functions on user interfaces (for example share on Facebook and Instagram or retweet on Twitter), has led to share being used as an intransitive verb, one which no longer requires a noun to follow it. In such uses, the verb has taken on a communicative meaning, particular to digital, alongside its sense of distribution or division and partaking in, referring to a mode of user engagement and content creation that can produce social and monetary value. ${ }^{23}$ In addition, sharing as an online practice implies particular kinds of relationships between participants, which are based on values, such as 'openness, trust and maybe a sense of commonality'. ${ }^{24}$

The extension of the domain of sharing has been accompanied by an extension of the tellability of previously intimate moments of life, often mundane and trivial. This extension has given rise to a proliferation of breaking news stories, described by Alexandra Georgakopoulou as 'stories of very recent (yesterday) and in some cases evolving (just now) events that once introduced into a conversation, can be further updated'. ${ }^{25}$ These stories tend to take the form of miniaturized versions of moments and events communicated in textual, visual, audio modes or a combination thereof, making up a narrative as posts accumulate over time and, often, across different social media platforms.

In addition to sharing trivial life moments, significant life events are also commonly broadcast online as small stories. The celebration of these events sustains competitive consumerist imperatives for creating ideal images that can be displayed on social media sites such as Facebook, Instagram or Pinterest as part of a continuous and positive public live feed. As Carly Gieseler shows in her study of gender-reveal parties, ${ }^{26}$ such celebrations constitute performances of liminality that reflect an increasing 
cultural trend-especially among younger social groups in the USA-for making the private public, drawing on the power of communitas '[i]n a cultural moment where events and rituals are often created to garner a share of the spotlight'. ${ }^{27}$

Performances of liminality online also include the sharing of transgressive events that mark a disruption in the flow of life, such as critical moments related to dying, death, and its attendant mourning. In such performances, existing norms of sharing on social media, which privilege displays of vernacular expression and positivity in posts, are prevalent. In expressions of public mourning, for example, users draw on existing repertoires of formulaic epitaphs ('Rest in Peace'), expressions of remembrance ('Forever Remembered, Forever Missed'; 'You may be gone, but you will never be forgotten') and sympathy ('Praying for you'; 'Our hearts are with you'). These are often reworked to foreground sharers' personal feelings and intimate relationship to the dead, as illustrated in this example, taken from a Facebook semi-public memorial group wall:

Hey man I just wanted to stop by and say I love you and miss you!!! See you soon boyyyyyy [smiley emoji ${ }^{28}$

Tributes like this are typical of posts in memorial groups on social network sites, such as Facebook, which are predominantly associated with memorialization as an integral part of the mourning work of bereaved individuals or groups. In these cases, there is often an expectation that tribute-posting will be sustained over time-or at least for as long as possible-as testimony to the life mourned.

As Elaine Kasket suggests in one of the early empirical studies of grieving on Facebook, ${ }^{29}$ such memorial commitment facilitates not only the maintenance of continuing bonds with the dead, but also the experiencing of communal bonds with a whole group of mourners. Continuing bonds are further facilitated by mobile media, whose intimate, portable, and pedestrian nature has deepened the penetration and personalization of social media use in everyday life. ${ }^{30}$ Based on their research into the uses of mobile media for memorialization and grieving, Kathleen M. Cumiskey and Larissa Hjorth note that such uses can foster the experience of co-presence, but also the 'haunting' of the deceased as a form of constant companionship. ${ }^{31}$

The emphasis on continuing bonds is not new. It echoes nineteenthcentury beliefs about the continuation of the friendships of life after death that Philippe Ariès discusses in his seminal book The Hour of Our Death. ${ }^{32}$ In terms of emotional communication, practices of online grieving and remembrance invoke elements of earlier (and still existing) 
practices of private and public management of emotions and intimacy through technologies of propinquity, such as the postcard. ${ }^{33}$ Practices of hyper-mourning are, then, to be approached as remediations ${ }^{34}$ of earlier media practices and rituals, in the sense that they involve the incorporation or representation of earlier media.

Hyper-mourning practices can also relate to moments of death events and crises of global resonance, when social media become mediators of the overall management of the crisis and its attendant mourning. For example, in the case of mourning threads and tributes shared on Twitter, Instagram, and other platforms, using hashtags, such as \#RIP, \#Remembering, or \#flyHigh, public remembrance has the potential to connect audiences on a large scale. These online reactions to death-news emerge in the context of an invitation to post an immediate response to the news of a specific death, taking the form of one-off tributes. The rapid accumulation of individual tributes contributes to the transformation of death in natural disasters or attacks into what Joana Sumiala et al. refer to as hybrid media events, ${ }^{35}$ whereby affect and cosmopolitan solidarity are mass-mobilized across a complex network of media, including internet-based and mobile communication technologies. In such events, emotion and memory are constructed in public modes of immediacy and hypermediacy.

The technologization and extension of memorialization to digital realms raise important questions about how, why, when, and who constructs and negotiates post-mortem identities, and what benefits or risks accompany such constructions. It also raises ethical and legal concerns about who has control over material accumulated during one's lifetime as well as after it. Such questions have been attracting increased media and scholarly interest in discussions of digital legacies and digital afterlives. ${ }^{36}$

The possibilities that social media platforms enable for the participation of wider and disparate audiences in flattened or collapsed contexts (also known as context collapse $)^{37}$ often entail the co-existence of different conditions and norms for public mourning. As a result, clashes around entitlement, or the right to share expressions of grief in public, ${ }^{38}$ are common, giving rise to polarized public attitudes to the appropriacy-or more often the inappropriacy - of their associated rhetorics and registers.

Addressing both the potential and limits of online grieving and memorialization, in what follows, I pinpoint the narrative constituents of such heterogeneous practices, starting from the key dimensions of this attested heterogeneity and then moving on to highlight the narrative and affective positions associated with what can be seen as typical modes of hyper-mourning. 


\section{NARRATIVE STANCE-TAKING IN HYPER-MOURNING}

Hyper-mourning practices vary along four main dimensions: first, the type of loss, which largely determines the specific kind of role-relationship in which grief is experienced and shared; second, the (intended) purposes of memorialization, i.e. who creates the memorial or shares a tribute, why, and when; third, the envisaged duration of the mourning activity, which refers to the expectations evident in the design of the memorial as a more or less permanent material entity; and fourth, the degree and types of interactivity, which are linked to the specific affordances of the site in which the memorial is hosted. The fourth dimension draws attention to who interacts with whom and how: for example, whether groups of mourners interact with each other or individual mourners interact directly with the dead.

These dimensions set the general frame in which participants take up narrative stancetaking positions. Narrative stancetaking has been suggested by Georgakopoulou as a key feature of emergent narrativity online, whereby 'an activity is being offered or taken up as a story, thereby positioning participants as tellers-recipients-(co)-tellers' ${ }^{39}$ Hyper-mourning practices vary, then, depending on the positions sharers can take up as tellers, co-tellers or (more or less distant) witnesses to a death and mourning spectacle.

Tellers use their social media profiles to share their personal story of loss. An example of this form of mourning tellership designed for a large audience is Sheryl Sandberg's long emotional post on Facebook following the death of her husband. ${ }^{40}$ Another case of taking up tellership positions is when sharers broadcast their unique experience of dying with networked audiences, known and unknown, using for example social media to voice unique experiences of incurable illness and dying, as in the case of young teenagers vlogging about cancer. ${ }^{41}$ These positions are also taken up by users who respond to the broadcast of personal stories of grieving or dying, by sharing a similar story of their own as a sign of support and identification with the story-sharer.

Co-tellers contribute memories and tributes with a view to participating in the creation of a collective mosaic of someone's life, even if they had known them only briefly, or in some cases not at all. Co-tellers can be expected to post one-off messages, for example R.I.P. messages on Twitter, or post more than once on a memorial site, as in the case of memorial Facebook pages created by (and for) a group of bereaved people. Cotellers often address the dead directly, either publicly or privately (using direct messaging applications), extending the bonds between those who are gone and those who are left behind. 
Lastly, witnesses to death events contribute their personal reactions to disasters and tragedies by noting, for instance, where they were when they heard the news, how they felt at the time and who they felt was to blame. This is especially notable in the case of the Facebook groups created after the Sandy Hook Elementary School shooting in Newtown, Connecticut (US) in 2012, or the Twitter storm that followed the school shootings at Marjory Stoneman Douglas High School in Parkland, Florida (US) in 2018. As mediated witnesses to these death events, participants engage mainly in hashtag mourning, given the potential of that mode to connect them to bigger audiences, as illustrated in the case of global reactions in the wake of attacks or natural disasters.

All of the above diverse hyper-mourning practices are typical instances of shared grieving and remembrance. Apart from their differences, they are all characterized by the use of digital resources for communicating, interacting, and performing emotion and the self, drawing on features of vernacular language. This language is often characterized by digital writing features, such as emoji and hashtags, and also draws on platformspecific vernaculars, for example images in photo-sharing websites. In addition, given the emphasis of digital technologies on interaction and participation, hyper-mourning involves poly-storying, ${ }^{42}$ that is, the emergence of a story by different participants at different points in time and with different orientations to the interaction and to each other.

The narrative positions of teller, co-teller, and witness make possible specific kinds of affective positioning ${ }^{43}$ at a relative proximity or distance to the death event, the audiences (known and unknown) and the affective self. Affective positioning can be a powerful heuristic for addressing aspects of affective communication as an integral part of identity (and identification) positioning processes beyond essentialist approaches to the study of emotion and identities.

\section{TOWARDS A TYPOLOGY OF HYPER-MOURNING}

Hyper-mourning can be viewed as broadly falling into five typical categories, as shown in Figure 2: 1. Participatory, 2. Motivational, 3. Connective, 4. Cosmopolitan, 5. Rebellious.

Participatory hyper-mourning refers to forms of mourning for the loss of a loved one in memorials created by bereaved groups, for example family, friends, and the broader community of which the deceased was a part. This type of memorial invites expressions of grief that seek to celebrate and re-signify the deceased's life. Such memorials tend to be designed as lasting sites for tributes, affording mourners the opportunity to be an integral part of memorialization as co-tellers of the deceased's 


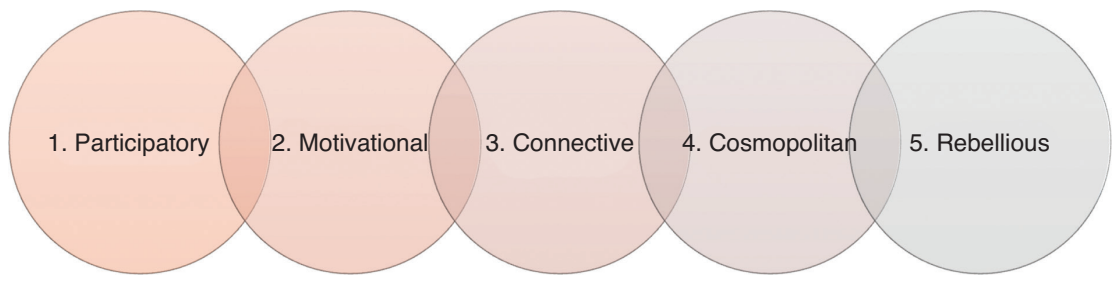

Figure 2. The heterogeneity of hyper-mourning.

life. The case of a memorial created by a group of classmates, in tribute to a young adult who lost his life in a car accident in 2012, is typical of this mode. On this Facebook group wall, memorialization is temporally extended by posting activity organized around recurrent dates, for example, the birthday and anniversary of their classmate's death (also known as deathversary), and featuring direct addresses to the dead person, in which sharers provide snapshots and updates from their everyday life. The function of this kind of memorialization activity is to re-integrate and maintain the dead as an absent co-present, one who can be imagined as a guardian-angel watching over family and friends in their everyday life. By posting, sharers participate as co-tellers in the collective weaving of their friend's life story and identity in the form of an emerging public record of grief that helps them to maintain continuing bonds with their friend. Participatory hyper-mourning remediates the practices of existing communities of the bereaved (such as talking to the dead in a graveyard or through prayers).$^{44}$ It extends grief and memorialization online socially, spatially, and temporally. ${ }^{45}$ It also affords increased opportunities for hyper-personalizing grief through acts of affective positioning that place sharers in an intimate relationship to the dead as well as to other networked mourners, allowing the dynamic inscription of their grieving self over time.

A second type of hyper-mourning is the motivational mode, which involves the use of social media for personalizing the documentation of illness, pre-figuring one's own death and mobilizing grief as an inspirational force for life. An example of this mode is cancer vlogging, where mainly young adults broadcast moments from their life, disrupted by illness. Taking up the empowering position of a teller, they inscribe their life as a source of motivation and inspiration for others ${ }^{46}$ while attempting to reclaim some control over how they will be remembered. Through their videos, these young cancer vloggers call for their viewers' support. In their role as influencers and advocates, they also seek to support others who may find themselves in a similar situation. These practices are 
embedded in attempts to voice the experience of illness speaking the truth of the wounded patient, ${ }^{47}$ at the same time as advocating for a range of philanthropic activities (such as charity and fundraising) ${ }^{48}$ connected to their personal story with an impact beyond their lifetime. Tellers negotiate their affective positioning to their illness and dying, and construct connections of emotional intimacy with known and unknown audiences who become the witnesses of their unique experience and, ultimately, the mourners of their inspirational life.

Connective forms of hyper-mourning encompass cases of sharing immediate, intense emotional reactions to death news. Such forms are illustrated in hashtag mourning in the wake of terrorist attacks, for example in the case of the social-mediatization of the Charlie Hebdo attacks, which took place in January 2015. Shortly after the attack became known, the logo Je Suis Charlie (I am Charlie), created by a designer from Paris and initially shared on Twitter as a personal reaction to the attacks, quickly became the symbol and iconic identity badge of people across the Western world who sympathized with the victims and the principle of freedom of speech. JeSuisCharlie hashtag tributes became a resource for connecting individuals around shared affective stances to the event, ${ }^{49}$ as did counter-stances through the circulation of the hashtag JeNeSuisPasCharlie (I am not Charlie). Since then, hashtag mourning has become an expected and highly conventionalized reaction to global events and attacks; it amplifies and scales up the affect and visibility of shared stories about a specific event. In this mode of hyper-mourning, death is mediatized at a relative distance from the sharer, with a predominant orientation to the scaling-up of moments of mourning and solidarity through one-off posts. Interactivity emerges as poly-storying, distributed across different participants and topics, rather than as direct interaction with the dead or other sharers, making available to an affective crowd various positions of ambient solidarity and membership of a group.

Other examples of this type of connective mourning include memorial pages and tributes created in reaction to school shootings. Such memorials are often connected to deaths that have been extensively covered in the media. Celebrity mourning can also be said to fall into this type, as it contributes to the more or less ephemeral bonding of affective fandom publics. Participants in such forms of hyper-mourning take up positions of mediated witnesses to a media spectacle at a relative distance from the event itself, while projecting their affective proximity to networked audiences who share their values and stances. Connective memorialization often helps catalyse offline vigils and memorials, as in the case of street rallies in solidarity with the victims of Charlie Hebdo, or public tributes to celebrities, illustrated in the case of the Brixton 
mural of David Bowie, ${ }^{50}$ or the (now dismantled) memorial garden for George Michael. ${ }^{51}$

A related, though slightly different, type of hyper-mourning is cosmopolitan sharing. This type also involves sharing of one-off immediate, intense emotional reactions to mediatized death events, connecting sharers to affective publics over cases of iconic death that are linked to broader social issues. This connection seems to have limited potential for more meaningful affective investment or offline mobilization. This is best illustrated in the case of hashtag mourning around the death of the 'Other', as in the cases of the viral sharing of images of the death of threeyear-old Alan Kurdi on the 2 September 2015, or more recently the image of the bodies of a father and daughter (Oscar Alberto Martinez Ramirez, 26, and his 23-month-old daughter Valeria) ${ }^{52}$ drowned at the border of Mexico on 26 June 2019. These grim visual stories of life and death are shared-often in photos reworked as memes or drawings-along with comments as part of wider attempts to raise awareness about the plight of 'the Other's' death. Despite the rapid dissemination of such images and their contribution to the scaling-up of global outrage and empathy, their scope tends to be limited to the digital realm, positioning sharers as oneoff empathetic witnesses to distant deaths and connecting sharers around displays of cosmopolitan empathy.

While in this type of hyper-mourning the emphasis is on creating a moment, rebellious death-writing of the moment attempts to create and sustain a movement based on bonds that extend beyond the media spectacle of a death, as discussed in Cindy Milstein's collection of essays on Rebellious Mourning. In this case, writing for precarious subjects is done by precarious subjects themselves, or by subjects identifying with them. Sharers use the affordances of social media visibility to draw attention to the discontents of their own lives and mobilize people around political action, as in the case of the Black Lives Matter movement. The movement-which unfolded in two inter-connected parts, one as \#BlackLivesMatter and another as a protest movement on the streets-emerged after the death in Sanford, Florida USA, of Trayvon Martin, an AfricanAmerican teenager shot in February 2012, and quickly became a point of social and cultural reference, calling attention to the persistence of race inequalities in the US and the race war waged against black lives. As Claudia Rankine notes, 'national mourning, as advocated by Black Lives Matter, is a mode of intervention and interruption [...]..$^{53}$

Rebellious mourning encompasses mourning for the tragedies of the Palestinian struggle, AIDS, border crossings, and police shootings. It is organized beyond the potential insularity of the personal, around a collective sense of grief and feelings as words or action that 'can open up 
cracks in the wall of the system, [...] pry open spaces of contestation and reconstruction, intervulnerability and strength, empathy and solidarity' ${ }^{54}$ Such acts are explicitly connected to and emerge from offline movements, although online can also prove a catalytic force in amplifying them. They look to expand and reinforce these movements in the long-term, positioning sharers as active witnesses willing to take a stand for deaths caused and silenced by rampant inequalities. It is, arguably, in rebellious forms of mourning that the political potential of hyper-mourning is located: sharers are interrogating whose lives are considered grievable and worthy of memorializing, and whose lives are dominating online visibilities as lives worth living, foregrounding the role of age, ethnicity, and class in this unspoken bio-politic.

The above types of hyper-mourning are seemingly presented here as separate from one another, based on how they sit across the four dimensions of type of loss, purposes, duration and interactivity types which I discussed earlier, and how they vary depending on their associated types of narrative stancetaking and affective positions. There are, however, cases when the boundaries between them are blurred. For instance, participatory memorialization on a Facebook memorial can include features of motivational mourning, co-weaving the life story of a deceased loved one as inspirational to others. Participatory hyper-mourning can also contain elements of connective mourning, in cases when mourning is mobilized as a symbolic resource for identity-construction around shared values or for cosmopolitan sharing of empathy. In some cases, participatory mourning in online environments can even be an integral part of rebellious mourning, remediating existing community bonds around a personal loss and mobilising it for social change.

\section{CONCLUDING REMARKS}

This article provides an overview of some of the emerging forms that mourning and memorialization take as they extend to online environments. These remediated practices incorporate and represent earlier media practices and rituals and many of their associated norms for performance. They also attest to the contemporary injunction to share and curate life and death in the here-and-now, alongside a 'felt' imperative to evaluate the online sharing of grief as being an often 'excessive' emotional reaction to loss.

The categories of hyper-mourning presented above are proposed as heuristics for drawing attention to their small story ingredients, ${ }^{55}$ constituents that are useful for mapping the diverse digital death- and memorial-scapes in relation to both their potential and their limits. These are 
mainly concerned with the kinds of affect, value, and visibilities afforded to networked publics, and the way that these become available to networked publics at an unprecedented speed, scale, and fusion ${ }^{56}$ of visual, textual, and symbolic modes. These modes allow a new immediacy for participating in the emotional intensities of the here-and-now of death events, and contributing to accumulating archives of memory and affect.

From personal loss to death in natural disasters and terrorism and celebrity death, digital technologies provide increased opportunities for networked publics to talk about death and loss in both serious and humorous ways, drawing on-as much as re-drawing-existing folk repertoires. As Trevor J. Blank notes, participants are given a sense of empowerment by the simulation of community, 'fusing the simulation of connectivity with the individual's psychological need to connect with others'. ${ }^{57}$ In summary, hyper-mourning fosters the personalization of loss and its public sharing with and for networked audiences as a resource for creating and scaling up affect, value, and visibility.

Given that grieving and remembering on social media are part of complex public performances online, they inevitably come with a set of challenges for sharers. These include the need to navigate the spectrum of visibility online, crossing one's own and others' understandings of privatepublic boundaries and drawing on different repertoires of mourning. Tensions often arise in this kind of emotional sharing, which frequently results in the erosion of 'traditional' hierarchies of mourning within the bereaved family and friends. These hierarchies relate to who is considered entitled to display grief publicly and share personal stories of grief with and for others (and when), and how such norms can be negotiated.

At the same time, the heightened visibility of mourning also increases the vulnerability of sharers ${ }^{58}$ evident in cases of what has become known as trolling or 'LOL-ing at tragedy'; ${ }^{59}$ these acts can represent broader criticisms of grieving in public as 'inauthentic'. ${ }^{60}$ Though hyper-mourning can provide networked users with a sense of empowerment through the different positions it makes available to mourners and participants in mourning, it can also increase risks of a sense of exposure and vulnerability.

Hyper-mourning also affords large audiences the scale-up affect, often at an unprecedented scale. This scaling-up of mourning makes it possible to mobilize collective empathy, which is instrumental for awarenessraising campaigns and fundraising, thus helping to create value out of mourning and memorialization or move people into politically charged action for social change.

Further studies on situated practices of online memorialization are needed, especially ones that pay close attention to users' individul 
trajectories across time. In addition, it is important to examine the different modulations of distance and proximity for performing emotion and the self through acts of affective positioning to the death event and the dead, known and unknown audiences, and the affective self in alignment or disalignment to master discourses of emotion.

A narrative approach to hyper-mourning, then, grounded in recent sociolinguistic research on story-telling practices known as small stories, can prove useful for the further study of the politics of personalization of mourning and grievability. ${ }^{61}$ The study of grieving and remembering with and for networked audiences invites continued reflection on how best to face the raw realities of death and grief collectively, and how to mobilize attention to broader social issues and the politics of precarious lives.

\section{WORKS CITED}

Ariès, Phillipe. Western Attitudes Toward Death from the Middle Ages to the Present. Trans. Patricia

M. Ranum. London: Marion Boyars, 1976.

Ariès, Phillipe. The Hour of Our Death. Trans. Helen Weaver. New York: Knopf, 1981.

Bassett, Debra J. 'Digital Afterlives: from Social Media Platforms to Thanatobots and Beyond.' In: Charles Tandy (ed.), Death and Anti-Death, Volume 16: Two Hundred Years after Frankenstein. Michigan: Ria University Press, 2018, in press.

Belshaw, John and Diane Purvey. Private Grief, Public Mourning: The Rise of the Roadside Shrine in British Columbia. Vancouver: Anvil Press, 2009.

Blank, Trevor J. The Last Laugh: Folk Humour, Celebrity Culture, and Mass-Mediated Disasters in the Digital Age. Madison: The University of Wisconsin Press, 2013.

Bolter, Jay David and Richard Grusin. Remediation: Understanding New Media. Cambridge: MIT Press, 1999.

Boyd, Danah and Alice E. Marwick. 'I Tweet Honestly, I Tweet Passionately: Twitter Users, Context Collapse, and the Imagined Audience.' New Media E Society 13:1 (2011) 114-133.

Brubaker, Jed, Gillian Hayes and Paul Dourish. 'Beyond the Grave: Facebook as a Site for the Expansion of Death and Mourning.' The Information Society: An International Journal 29:3 (2013) 152-163.

Butler, Judith. Precarious Life: The Power of Mourning and Violence. London: Verso, 2004.

Cumiskey, Kathleen M. and Larissa Hjorth. Haunting Hands: Mobile Media Practices and Loss. Oxford: Oxford University Press, 2017.

De Lillo, Don. White Noise. London: Picador, 1985.

Frank, Arthur W. The Wounded Storyteller. Body, Illness, and Ethics. Chicago and London: University of Chicago Press, 1995.

Francis, Doris, Georgina Neophytou and Leonie Kellaher. The Secret Cemetery. Oxford: Berg, 2005.

Georgakopoulou, Alexandra. 'Small Stories Research: A Narrative Paradigm for the Analysis of Social Media.' In: L. Sloan and A. Quan-Haase (eds.), The SAGE Handbook of Social Media Research Methods. London: Sage, 2016, 266-281.

Georgakopoulou, Alexandra. 'Sharing the Moment as Small Stories: The Interplay Between Practices \& Affordances in the Social Media-Curation of Lives.' Narrative Inquiry 27:2 (2017) 311-333. 
Georgakopoulou, Alexandra and Korina Giaxoglou. 'Emplotment in the Social Mediatization of the Economy: the Poly-Storying of Economist Yanis Varoufakis.' Language @ Internet 16, article 6 (2018).

Giaxoglou, Korina. '\#JeSuisCharlie? Hashtags as Narrative Resources in Contexts of Ecstatic Sharing.' Discourse, Context and Media 22 (2018) 13-20.

Giaxoglou, Korina. 'Sharing Small Stories of Life and Death Online: Death-Writing of the Moment.' The European Journal of Life Writing 8 (2019) 118-142.

Giaxoglou, Korina. A Narrative Approach to Social Media Mourning: Small Stories and Affective Positioning. London: Routledge, forthcoming.

Gieseler, Carly. 'Gender-Reveal Parties: Performing Community Identity in Pink and Blue.' Journal of Gender Studies 27:6 (2017) 661-671.

Ito, Mizuko. 'Introduction: Personal, Portable, Pedestrian.' In: Mizuko Ito, Dasuke Okabe and Misa Matsuda (eds.), Personal, Portable, Pedestrian: Mobile Phones in Japanese Life. Cambridge: MIT Press, 2005, 1-16.

Jacobsen, Michael Hviid. "Spectacular Death"-Proposing a New Fifth Phase to Phillipe Ariès's Admirable History of Death.' Humanities 5:19 (2016) 1-20.

John, Nicholas. The Age of Sharing. Malden: Polity Press, 2017.

Johnson, Richard. 'Exemplary Differences: Mourning (and Not Mourning) a Princess.' In: Adrian Kear and Deborah Lynn Steinberg (eds.), Mourning Diana: Nation, Culture and the Performance of Grief. London and New York: Routledge, 1999.

Jones, Rodney and Chris Hafner. Understanding Digital Literacies. A Practical Introduction. London and New York: Routledge, 2012.

Jupp, Peter and Tony Walter. 'The Healthy Society: 1918-98.' In: Peter Jupp (ed.), Death in England: An Illustrated History. Manchester: Manchester University Press, 1999, 256-283.

Kasket, Elaine. 'Continuing Bonds in the Age of Social Networking: Facebook as a ModernDay Medium.' Bereavement Care 31 (2012) 62-69.

Kasket, Elaine. All the Ghosts in the Machine. Illusions of Immortality in the Digital Age. London: Robinson, 2019.

Kear, Adrian and Deborah Lynn Steinberg. 'Ghost Writing.' In: Adrian Kear and Deborah Lynn Steinberg (eds.), Mourning Diana: Nation, Culture and the Performance of Grief. London and New York: Routledge, 1999, 1-14.

Khapaeva, Dina. The Celebration of Death in Contemporary Culture. Michigan: The University of Michigan Press, 2017.

Klastrup, Lisbeth. “'I Didn't Know Her, But...”: Parasocial Mourning of Mediated Deaths on Facebook RIP Pages.' New Review of Hypermedia and Multimedia 21:1-2 (2015) 146-164.

Livingston, Steven and Lance W. Bennett. 'Gatekeeping, Indexing and Live-event News: Is Technology Altering the Construction of News?' Political Communication 20:4 (2003) 363-380.

McNeill, Laurie and John David Zuern. 'Online Lives 2.0: Introduction.' Biography 38:2 (2015) x-xvi.

Milne, Esther. Letters, Postcards, Email: Technologies of Presence. London: Routledge, 2010.

Milstein, Cindy (ed.). Rebellious Mourning: The Collective Work of Grief. Chico, Edinburgh, Baltimore: AK Press, 2017.

Morse, Tal. The Mourning News: Reporting Violent Death in a Global Age. New York: Peter Lang Publishing, 2017.

Phillips, Whitney and Ryan M. Milner. The Ambivalent Internet: Mischief, Oddity, and Antagonism Online. Malden: Polity Press, 2017.

Phillips, Whitney. 'LOLing at Tragedy: Facebook Trolls, Memorial Pages and Resistance of Grief Online.' First Monday 16:12 (2011) n.p.

Poletti, Anna and Julie Rak. 'Introduction: Digital Dialogues.' In: Anna Poletti and Julie Rak (eds.), Identity Technologies: Constructing the Self Online. Madison: University of Wisconsin Press, 2014, 3-22. 
Rankine, Claudia. 'The Condition of Black Life is One of Mourning.' In: Cindy Milstein (ed.), Rebellious Mourning: The Collective Work of Grief. Chico, Edinburgh, Baltimore: AK Press, 2017, 25-39.

Stage, Carsten. Networked Cancer: Affect, Narrative and Measurement. Basingstoke: Palgrave Macmillan, 2017.

Sumiala, Joanna, Katja Valaskivi, Minttu Tikka and Jukka Huhtamäki. Hybrid Media Events: The Charlie Hebdo Attacks and the Global Circulation of Terrorist Violence. Bingley: Emerald Publishing, 2018.

Turkle, Sherry. Alone Together: Why We Expect More from Technology and Less from Each Other. New York: Basic Books, 2011.

\section{ABOUT THE AUTHOR}

Korina Giaxoglou is a Lecturer of English Language and Applied Linguistics at the Open University, UK, where she convenes the interdisciplinary Health Discourse Research Group. Her research focuses on story sharing, affective positioning, and mourning in folklore and social media communication. Her work has appeared in edited volumes, special issues, and peer-reviewed journals, including Discourse, Context and Media, Social Media + Society, and Pragmatics. Her research monograph, entitled A Narrative Approach to Social Media Mourning: Small Stories and Affective Positioning, is forthcoming from Routledge. E-mail: Korina.Giaxoglou@open.ac.uk.

\section{NOTES}

1 'Grumpy Cat Dies Aged Seven: "Some Days are Grumpier than Others."' The Guardian, 17 May 2019, https://www.theguardian.com/technology/2019/may/17/grumpy-cat-diesseven-internet-meme-gif. Date accessed: 22 July 2019; 'Gone but not Forgotten. World Famous Grumpy Cat Dies Aged 7 after Making her Owner Millions.' The Sun, 17 May, https://www.thesun.co.uk/news/9095687/grumpy-cat-dead-memes/. Date accessed: 22 July 2019; CBS ‘Grumpy Cat, Viral Sensation has Died at Age 7’. CBS News, 17 May 2019, https://www.cbsnews.com/news/grumpy-cat-has-died-viral-cat-mme-sensation-dies-atage-7-cause-of-death-complications-after-urinary-tract-infection/. Date accessed: 22 July 2019.

2 Jones, Rodney, and Chris Hafner. Understanding Digital Literacies. A Practical Introduction. London and New York: Routledge, 2012 (43).

3 Ariès, Philippe. Western Attitudes Toward Death from the Middle Ages to the Present. Trans. Patricia M. Ranum. London: Marion Boyars, 1976 (56).

4 Khapaeva, Dina. The Celebration of Death in Contemporary Culture. Michigan: The University of Michigan Press, 2017 (1-2).

5 Topping, Alexandra. 'Michael Jackson's death on Twitter-from Demi Moore to fan-inthe-street.' The Guardian, 26 June 2009, https://www.theguardian.com/music/2009/ jun/26/twitter-michael-jackson-dead. Date accessed: 25 April 2020.

6 See Morse, Tal. The Mourning News: Reporting Violent Death in a Global Age. New York: Peter Lang Publishing, 2017.

7 Livingston, Steven and Lance W. Bennet, 'Gatekeeping, Indexing and Live-event News: Is Technology Altering the Construction of News?' Political Communication 20:4 (2003) 363-380 365 . 
8 Jacobsen, Michael Hviid. "Spectacular Death"-Proposing a New Fifth Phase to Phillipe Ariès's Admirable History of Death.' Humanities 5:19 (2016) (1-20).

9 Kear, Adrian and Deborah Lynn Steinberg. 'Ghost Writing.' In: Adrian Kear and Deborah Lynn Steinberg (eds.), Mourning Diana: Nation, Culture and the Performance of Grief. London and New York: Routledge, 1999 (3).

10 For a discussion of the issues around some commentators' puzzlement about the outpouring of grief for the death of Princess Diana, see Richard Johnson. 'Exemplary Differences: Mourning (and Not Mourning) a Princess.' In: Adrian Kear and Deborah Lynn Steinberg (eds.), Mourning Diana: Nation, Culture and the Performance of Grief. London and New York: Routledge, 1999 (15-40).

11 Suclu, Peter. 'Mourning Kobe Bryant: Are Condolences Really Best Shared on Social Media?' Forbes, 28 January 2020, https://www.forbes.com/sites/petersuciu/2020/01/28/ are-condolences-really-best-shared-on-social-media/. Date accessed: 20 April 2020.

12 See thread 'People who post about family deaths on social media are the worst.' Reddit, 2019, https://www.reddit.com/r/unpopularopinion/comments/9i7v2n/people_who_ post_about_family_deaths_on_social/.Date accessed: 20 April 2020.

13 Poletti, Anna and Julie Rak. 'Introduction: Digital Dialogues.' In: Anna Poletti and Julie Rak (eds.), Identity Technologies: Constructing the Self Online. Madison: University of Wisconsin Press, 2014 (5).

14 Idem (7).

15 Georgakopoulou, Alexandra. 'Small Stories Research: A Narrative Paradigm for the Analysis of Social Media.' In: L. Sloan and A. Quan-Haase (eds.), The SAGE Handbook of Social Media Research Methods. London: Sage, 2016 (266-281).

16 For a detailed discussion of the different types of hyper-mourning mentioned in this article, see Giaxoglou, forthcoming.

17 De Lillo, Don. White Noise. London: Picador, 1985 (75).

18 Belshaw, John and Diane Purvey. Private Grief, Public Mourning. The Rise of the Roadside Shrine in British Columbia. Vancouver: Anvil Press, 2009 (130).

19 Idem (102-103).

20 Idem (112).

21 Turkle, Sherry. Alone Together: Why We Expect More from Technology and Less from Each Other. New York: Basic Books, 2011.

22 John, Nicholas. The Age of Sharing. Malden: Polity Press, 2017.

23 Idem (27).

$24 \operatorname{Idem}(7)$.

25 Georgakopoulou, Alexandra. 'Sharing the Moment as Small Stories: The Interplay Between Practices \& Affordances in the Social Media-Curation of Lives.' Narrative Inquiry 27:2 (2017) (268).

26 Gieseler, Carly. 'Gender-Reveal Parties: Performing Community Identity in Pink and Blue.' Journal of Gender Studies 27:6 (2017) (661-671).

27 Idem (7).

28 Facebook semi-public R.I.P. group, author's data.

29 Kasket, Elaine. 'Continuing Bonds in the Age of Social Networking: Facebook as a Modern-Day Medium.' Bereavement Care 31 (2012) 68.

30 Ito, Mizuko, Dasuke Okabe and Misa Matsuda (eds.). Personal, Portable, Pedestrian: Mobile Phones in Japanese Life. Cambridge: MIT Press, 2005.

31 Cumiskey, Kathleen M. and Larissa Hjorth. Haunting Hands: Mobile Media Practices and Loss. Oxford: Oxford University Press, 2017 (174-175).

32 Ariès, Philippe. The Hour of Our Death. Trans. Helen Weaver. New York: Knopf, 1981 (471).

33 It is notable that debates about the blurring of the private-public domains which have been central in discussions about the impact of social media, were also rampant in 
the context of the advent of the postcard: see Esther Milne. Letters, Postcards, Email: Technologies of Presence. London: Routledge, 2010.

34 Jay David Bolter and Richard Grusin. Remediation: Understanding New Media. Cambridge: MIT Press, 199 (45).

35 Joanna Sumiala, Katja Valaskivi, Minttu Tikka, Jukka Huhtamäki. Hybrid Media Events: The Charlie Hebdo Attacks and the Global Circulation of Terrorist Violence. Bingley: Emerald Publishing, 2018 (15).

36 Kasket, Elaine. All the Ghosts in the Machine. Illusions of Immortality in the Digital Age. London: Robinson, 2019; Bassett, Debra J. 'Digital Afterlives: from Social Media Platforms to Thanatobots and Beyond.' In: Charles Tandy (ed.), Death and Anti-Death, Volume 16: Two Hundred Years after Frankenstein. Michigan: Ria University Press, 2018.

37 Boyd, Danah, and Alice E. Marwick. 'I Tweet Honestly, I Tweet Paassionately: Twitter Users, Context Collapse, and the Imagined Audience.' New Media E Society 13:1 (2011) 114-133.

38 Wilmot, Claire. 'The Space Between Mourning and Grief.' The Atlantic, 8 June 2016, https://www.theatlantic.com/entertainment/archive/2016/06/internetgrief/485864/. Date accessed: 22 July 2019.

39 Georgakopoulou, Alexandra, 2016 (275).

40 'Sheryl Sandberg on Husband's Death: I have Lived 20 Years in these 30 Days.' The Guardian, 3 June 2015, https://www.theguardian.com/technology/2015/jun/03/ sheryl-sandberg-facebook-death-david-goldberg. Date accessed: 22 July 2019.

41 A selection of popular cancer vlogs includes: Emily Hayward's vlog described as a vlog 'on fitness, coaching, wellness, life and my battle with cancer,' https://www.youtube. com/channel/UCa6sLJCWdaRF2yS-gd_NkeQ; Charlotte Eade's vlog, https://www. youtube.com/watch?v=4ShO2QZ98Ro; Dan Thomas (PeeWeeTom), https://www.youtube.com/user/peeweetoms.

42 This term is discussed in an analysis of the social-mediatization of the Greek economy in Alexandra Georgakopoulou and Korina Giaxoglou. 'Emplotment in the Social Mediatization of the Economy: the Poly-Storying of Economist Yanis Varoufakis.' Language @ Internet 16, article 6 (2018).

43 See Giaxoglou, Korina. A Narrative Approach to Social Media Mourning: Small Stories and Affective Positioning. London: Routledge, forthcoming.

44 See Francis, Doris, Georgina Neophytou and Leonie Kellaher. The Secret Cemetery. Oxford: Berg, 2005.

45 Brubaker, Jed, Gillian Hayes and Paul Dourish. 'Beyond the Grave: Facebook as a Site for the Expansion of Death and Mourning.' The Information Society: An International Journal 29:3 (2013) (152-163).

46 An example of a motivational cancer vlog is the vlog maintained by Charlotte Eades (1997-2016), who documented her life with and despite her illness from 2014 to her last days. https://www.youtube.com/channel/UC6bE4OSCx99n7pF3vtZQMrw.

47 Frank, Arthur W. The Wounded Storyteller. Body, Illness, and Ethics. Chicago and London: University of Chicago Press, 1995.

48 See Stage, Carsten. Networked Cancer: Affect, Narrative and Measurement. Basingstoke: Palgrave Macmillan, 2017.

49 See Giaxoglou, Korina. '\#JeSuisCharlie? Hashtags as Narrative Resources in Contexts of Ecstatic Sharing.' Discourse, Context and Media 22 (2018) 13-20.

50 David Bowie Graffiti Mural. London, England. Atlas Obscura. https://www.atlasobscura. com/places/david-bowie-mural. Date accessed: 10 September 2019.

51 George Michael Memorial. London, England. Atlas Obscura. https://www.atlasobscura. com/places/george-michael-memorial-garden. Date accessed: 10 September 2019. 
52 Timmon, Patrick, Martin Hodgson, and David Agren. 'Shocking Photo of Drowned Father and Daughter Highlights Migrants' Border Peril.' The Guardian, 26 July 2019, https://www.theguardian.com/us-news/2019/jun/25/photo-drowned-migrantdaughter-rio-grande-us-mexico-border. Date accessed: 10 September 2019.

53 Rankine, Claudia. 'The Condition of Black Life is One of Mourning.' In: Cindy Milstein (ed.), Rebellious Mourning: The Collective Work of Grief. Chico, Edinburgh, Baltimore: AK Press, 2017 (38).

54 Milstein, Cindy (ed.). Rebellious Mourning: The Collective Work of Grief. Chico, Edinburgh, Baltimore: AK Press, 2017 (8-9).

55 For a more detailed discussion of each of these types of hyper-mourning, see Giaxoglou, Korina, forthcoming.

56 The two main features of the new communication tools, according to Philippe Lejeune, are fusion and speed. Poletti and Rak, 2014 (17).

57 Blank, Trevor J. The Last Laugh: Folk Humour, Celebrity Culture, and Mass-Mediated Disasters in the Digital Age. Madison: The University of Wisconsin Press, 2013 (104-105).

58 The way this climate of exposure and risk arising from the conflation of private and public space is shaping online self-representation, and also to some extent transforming the selves performing them, is discussed in McNeill, Laurie and John David Zuern. 'Online Lives 2.0: Introduction.' Biography 38:2 (2015) viii.

59 Phillips, Whitney. 'LOLing at Tragedy: Facebook Trolls, Memorial Pages and Resistance of Grief Online.' First Monday 16:12 (2011).

60 Phillips, Whitney and Ryan M. Milner. The Ambivalent Internet: Mischief, Oddity, and Antagonism Online. Malden: Polity Press, 2017.

61 Butler, Judith. Precarious Life: The Power of Mourning and Violence. London: Verso, 2004 (37). 